\title{
Avaliação da cicatrização óssea em falha mandibular com auto-enxerto ósseo associado à suspensão celular de medula óssea autógena: estudo experimental*
}

\author{
CRISTIANO GOMES
}

Emerson Antonio Contesini (Orientador - UFRGS)

Marcelo Meller Alievi (Co-orientadora - UFRGS)

Banca: Ney Luis Pippi (UFSM), Elizabeth Obino Cirne-Lima (UFRGS), João Batista Burzlaff (UFRGS)

Defeitos mandibulares secundários a traumas, e neoplasias ou deformidades, freqüentemente representam um desafio para cirurgiões bucomaxilofaciais e ortopedistas. O objetivo deste trabalho é avaliar a cicatrização óssea de autoenxerto da crista ilíaca associado à terapia celular da medula óssea. Foi criado um defeito ósseo de 10x5x5 mm na mandíbula de 28 coelhos, distribuídos em grupo controle (14 animais), reparados com auto-enxerto de crista ilíaca, e grupo experimental (14 animais), em que o auto-enxerto foi associado a células mononucleares da medula óssea autógena do fêmur. Foram realizadas radiografias semanais da região operada e análise histológica de sete animais de cada grupo aos 15 e 30 dias do pósoperatório. Houve um aumento gradativo da densidade óssea, com 85,71\% dos animais do grupo experimental e 42,85\% do grupo controle apresentando formação de ponte óssea 28 dias após a cirurgia. Na análise histopatológica aos 15 dias, os enxertos eram facilmente visualizados e a atividade das células fagocitárias era intensa. Já aos 30 dias, a sua visualização era mais difícil e, quando possível, apenas um resquício era visualizado. Os resultados sugerem que a adição de células mononucleares da medula óssea favorece a cicatrização do auto-enxerto em defeitos mandibulares de coelhos.

Descritores: reconstrução mandibular, regeneração óssea, enxerto.

*Dissertação de Mestrado n.487 (Especialidade: Cirurgia Experimental). 77f. Programa de Pós-graduação em Ciências Veterinárias [www.ufrgs.br/ ppgcv], Faculdade de Veterinária - Universidade Federal do Rio Grande do Sul (UFRGS), Porto Alegre/RS. CORRESPONDÊNCIA: C. Gomes [crisgomes98@hotmail.com]. 


\title{
Evaluation of the bone regeneration in mandibular defect with auto graft bone combined with cell suspension from bone marrow: experimental study**
}

\author{
CRISTIANO GOMES
}

\author{
Emerson Antonio Contesini (Adviser - UFRGS)
}

Marcelo Meller Alievi (Co-adviser - UFRGS)

Committee: Ney Luis Pippi (UFSM), Elizabeth Obino Cirne-Lima (UFRGS), João Batista Burzlaff (UFRGS)

Bone defects secundary to tumor, trauma or deformity often presents a significant problem for oral and maxillofacial surgeons and orthopedists. The aim of the present study is to investigate the bone regeneration of the autograft from iliac creast associated to cellular therapy with bone marrow. A bone defect was created with 10x5x5 mm in 28 rabbits mandible. The control group (14 animals) was repaired with autograft of the iliac creast and the experimental group (14 animals) was associated to mononuclear cells from the bone marrow of the femur. Weekly radiographs were done from the surgery region and histophatology analysis was made in seven animals of which group, in 15 and 30 days after surgery. A gradative increase of bone density was seen and the experimental animals presented the bone bridge in $85,71 \%$ of the cases, while in control group only $42,85 \%$ of the animals had the same found 28 days after surgery. The histophatologic analysis showed that in 15 days the autografts were easily seen and the phagocytary cells activity were intense. Although in 30 days it visualisation was more difficult and when possible, only a vestige was seen. The results of this study suggest that the mononuclear cells from the bone marrow can support the autograft regeneration in mandible defects in rabbits.

Key words: mandibular reconstruction, bone regeneration, graft. 